\title{
Clostridium difficile tcdA DNA Measurement
}

National Cancer Institute

\section{Source}

National Cancer Institute. Clostridium difficile tcdA DNA Measurement. NCI Thesaurus.

Code C150859.

The determination of the amount of tcdA DNA produced by Clostridium difficile present in a sample. 